Acta vet. scand. $1976,17,1-14$.

From the Department of Pharmacology and Toxicology, Royal Veterinary and Agricultural University, Copenhagen, Denmark.

\title{
PHARMACOKINETICS OF HEXOBARBITAL, SULPHADIMIDINE AND CHLORAMPHENICOL IN NEONATAL AND YOUNG PIGS
}

\author{
By \\ Ove Svendsen
}

\begin{abstract}
SVENDSEN, OVE: Pharmacokinetics of hexobarbital, sulphadimidine and chloramphenicol in neonatal and young pigs. Acta vet. scand. 1976, 17, 1-14. - Half-life and apparent specific volume of distribution of hexobarbital, sulphadimidine and chloramphenicol were investigated in newborn, $1,3,5$ and 8 weeks old pigs. Hexobarbital sleeping time and plasma concentration of hexobarbital at recovery were measured in the same age groups. The half-life of hexobarbital and chloramphenicol was long in newborn pigs but decreased fast during the first week after birth. From 1 to 8 weeks after birth the decrease was less pronounced. The half-life of sulphadimidine increased during the first 3 weeks of life, but in 1 and 3 weeks old pigs the amount of $\mathrm{N}^{4}$-acetylated sulphadimidine in plasma at 200 min. after the injection was higher than in the newborn pigs.
\end{abstract}

The apparent specific volume of distribution of hexobarbital, sulphadimidine and chloramphenicol was changed in different ways from birth to 8 weeks of age.

The hexobarbital sleeping time was very long in the newborn pigs and decreased until 3 weeks of age. The concentration of hexobarbital in plasma at recovery was unchanged from birth to 8 weeks of age.

The concentration of chloramphenicol metabolites in plasma 100 min. after the injection increased very fast during the 8 weeks of observation. The concentration of $\mathrm{N}^{4}$-acetylated sulphadimidine in plasma at 200 min. after the injection increased from birth to 1 week of age, then it decreased.

The data are stressing that the neonatal pig is a convenient model for pharmacokinetic testing of drugs used as pharmacotherapeutics in neonatal life.

pharmacokinetics; hexobarbital; sulphadimidine; chloramphenicol; neonatal pigs. 
It has long been known that neonatal and adult mammals differ in their response to different drugs. Several reviews dealing with this subject have been published in recent years (Nyhan 1961, Done 1966, Yaffe 1966, Mirkin 1970, Fouts 1973).

The most obvious reason for this difference is the low level of drug metabolizing enzyme activity in the liver of neonatal animals as first reported by Jondorf et al. (1958) and Fouts \& Adamson (1959) using microsomes from fetal and newborn laboratory animals. Since these early works the activity of microsomal drug metabolizing enzyme systems has been widely investigated (Basu et al. 1971, Henderson 1971, Fouts 1973, Rane et al. 1973 ), and as a rule the activities are low in neonatals and generally increasing to adult level during the first 3 to 5 weeks after birth.

Donald \& Raventós (1939) found that the hexobarbital sleeping time in neonatal pigs is decreasing with age and reaching the adult level about 3 weeks from birth. Low levels of hepatic microsomal drug metabolism in neonatal pigs have been reported by Short \& Davis (1970) and Short \& Stith (1973).

Pharmacokinetics of several drugs have been studied in neonatal infants (Fichter \& Curtis 1956, Gladtke \& Rind 1965, Sereni et al. 1965, 1968, Krauer et al. 1968, Simon et al. 1972). Generally these studies showed long elimination half-lives of the drugs due to immaturity of the hepatic metabolism and renal excretion. Such studies are difficult to carry out in traditional laboratory animals. Therefore, neonatal and young pigs were chosen in the present investigation of pharmacokinetic parameters of 3 drugs.

\section{Animals}

\section{MATERIALS AND METHODS}

Neonatal and young pigs (Danish landrace breed) were obtained from a local breeder. The sows were fed barley enriched with 51 acidified milk until five weeks after delivery, and afterwards the fodder was added a protein-mixture $(180-200 \mathrm{~g}$ per day) containing soya meal, meat- and bone meal, fish meal, vitamins and mineral salt. The neonatal pigs got milk only from the sow until 3 weeks of age. From this time they got creep feeding consisting of barley, oats, wheat, soya meal, skim-milk powder, fish meal, dried yeast, vitamins and mineral salt ad libitum.

For the study of plasma half-life newborn, 1, 3, 5 and 8 weeks 
old pigs were used. The half-lives are calculated as the average of the results from at least 4 pigs ( 2 females and 2 males).

\section{Half-life and apparent specific volume of distribution}

Hexobarbital (enhexymalum NFN), sulphadimidine (sulfadimidinum NFN) and chloramphenicol (chloramphenicolum NFN) were administered intravenously. The dose of chloramphenicol was $50 \mathrm{mg} / \mathrm{kg}$ b.wt. as a $10 \%(\mathrm{w} / \mathrm{v})$ solution in propylene glycol. The dose of hexobarbital and sulphadimidine was 30 and $100 \mathrm{mg} / \mathrm{kg}$ b.w.t., respectively, and both were aqueous solutions at 6 and $20 \%(\mathrm{w} / \mathrm{v})$, respectively.

The compounds except chloramphenicol were dissolved just before use. The chloramphenicol was dissolved the day before use.

In newborn and 1 week old pigs the intravenous administration was done through the bijugular trunc near the thoracal aperture with the pigs fixed in dorsal recumbency, while the intravenous administration in 3,5 and 8 weeks old pigs was performed through an ear vein. Blood samples $(3-5 \mathrm{ml})$ were collected $1 / 2,1,2,3,4,5$ and $6 \mathrm{hrs}$. after the injection except in newborn pigs, where samples were collected $1 / 2,1,2,4$ and $6 \mathrm{hrs}$. after the injection. For the estimation of half-life of hexobarbital and chloramphenicol in 5 and 8 weeks old pigs blood samples were also taken $3 / 4$ and $1 \frac{1}{2}$ hrs. after the injection.

The concentrations of hexobarbital in plasma were estimated by the method of Cooper \& Brodie (1955). The method described by Bratton \& Marshall (1939) was used for the estimation of concentrations of free sulphadimidine. The concentration of total sulphadimidine was determined on the same samples after hydrolysis with $\mathrm{HCl}$. The concentration of $\mathrm{N}^{4}$-acetylated sulphadimidine was calculated as the difference between the concentration of total and that of free sulphadimidine.

The concentrations of biologically active chloramphenicol were determined according to the method of Kakemi et al. (1962) modified by Hughes \& Diamond (1964) while total chloramphenicol (free chloramphenicol plus metabolites with an aromatic nitro group) was measured by the method of Bessman \& Stevens (1950). The method for the estimation of sulphadimidine and the method of Bessman \& Stevens had to be modified, because the proteins in plasma from newborn and 1 week old pigs could 
not be sufficiently precipitated. The modification of the former method comprised addition of $0.8 \mathrm{ml} 5 \%$ bovine albumine solution prior to precipitation. The modification of the method of Bessman \& Stevens comprised protein precipitation according to the method of Glazko (1967) after addition of $3 \mathrm{ml} 5 \%$ bovine albumine solution. For the reduction of the aromatic nitro group in chloramphenicol $190 \mathrm{mg}$ zinc powder was used.

The concentrations of the drugs found in plasma were plotted against time in a semilogarithmic coordinate system. From the slope of the linear regression lines through these points the plasma half-life was calculated.

From each half-life curve the concentration of free sulphadimidine and biologically active chloramphenicol was calculated at 200 and 100 min., respectively. The concentration of total sulphadimidine and total chloramphenicol was at the same time calculated by extrapolating the concentrations estimated from the blood samples taken before and after the time of interest.

The apparent specific volume of distribution per $\mathrm{kg} \mathrm{b}$.wt. was determined according to Butler (1971) from the formula

$$
\mathrm{V}^{\prime} \mathrm{d}=\frac{\mathrm{Q}}{\mathrm{C}} \times 100
$$

where $Q$ is the dose injected in $\mathrm{mg} / \mathrm{kg} \mathrm{b}$.wt. and $\mathrm{C}$ is the extrapolated zero time concentration in $\mu \mathrm{g} / \mathrm{ml}$ plasma and is given in per cent of body weight.

\section{Sleeping time}

The pigs receiving hexobarbital fell asleep and the sleeping time was measured. Sleeping time was defined as the time in minutes from the injection until the pigs could stand (Donald $\&$ Raventós 1939). From the half-life curves the concentrations of hexobarbital in plasma at the end of sleeping time were calculated.

\section{Statistics}

The statistical calculations were made in accordance to standard methods (Kemp 1955) and the results are given as average \pm s.e.m. 


\section{Hexobarbital}

\section{RESULTS}

The disappearance of hexobarbital follows first-order kinetics during the observation period from $30 \mathrm{~min}$. to $6 \mathrm{hrs}$. A very fast decrease of the plasma half-life during the first week of life is illustrated in Table 1. The half-life decreased further from 1 to 3 weeks of age and was after that unchanged.

T a ble 1. Effect of age on plasma half-life of hexobarbital, sulphadimidine and chloramphenicol.

\begin{tabular}{|c|c|c|c|}
\hline \multirow{2}{*}{$\begin{array}{l}\text { Age of } \\
\text { pigs }\end{array}$} & \multicolumn{3}{|c|}{ Plasma half-life } \\
\hline & hexobarbital & sulphadimidine & chloramphenicol \\
\hline newborn & $301^{\mathrm{a}} \pm 24$ & $775 \underset{(5)}{ \pm} 35$ & $368^{\mathrm{a}} \pm 27$ \\
\hline 1 week & $148 \underset{(4)}{ \pm} 16$ & $787 \underset{(8)}{ \pm} 13$ & $\begin{array}{c}141^{\mathrm{a}} \pm 9 \\
(10)\end{array}$ \\
\hline 3 weeks & $113 \underset{(11)}{ \pm} 8$ & $944 \underset{(5)}{ \pm} 100$ & $\begin{array}{c}74^{b} \pm 8 \\
(6)\end{array}$ \\
\hline 5 weeks & $118 \underset{(6)}{ \pm} 22$ & $766 \underset{(8)}{ \pm} 73$ & $63 \underset{(4)}{ \pm} 7$ \\
\hline 8 weeks & $\begin{array}{c}103^{c} \pm 11 \\
(5)\end{array}$ & $548^{a} \pm 39$ & $\begin{array}{c}49^{b} \pm 4 \\
(9)\end{array}$ \\
\hline
\end{tabular}

The values are in minutes \pm s.e.m. In brackets the number of pigs.

a The value is significantly different $(P<0.05)$ from all other age groups.

b The value is significantly different $(P<0.05)$ from all other age groups except the 5 weeks old group.

c The value is significantly different $(P<0.05)$ from the 1 week old group.

The average sleeping time (Table 3 ) is very long in the newborn pigs and decreases fast during the first 3 weeks of life, particularly during the first week. From 3 to 8 weeks of age no further decrease is observed. The calculated mean concentration of hexobarbital in plasma at the end of sleeping time (Table 3 ) is a little higher in 1 week old pigs than in the other groups of age.

The effect of age on the mean apparent specific volume of distribution is illustrated in Table 2 . The volume increases significantly $(P<0.05)$ during the first 3 weeks of age. 
T a b le 2. Effect of age on the apparent specific volume of distribution for hexobarbital, sulphadimidine and chloramphenicol.

\begin{tabular}{|c|c|c|c|}
\hline \multirow{2}{*}{$\begin{array}{l}\text { Age of } \\
\text { pigs }\end{array}$} & \multicolumn{3}{|c|}{ Apparent specific volume of distribution } \\
\hline & hexobarbital & sulphadimidine & chloramphenicol \\
\hline newborn & $140.4^{\mathrm{a}} \underset{(4)}{ \pm} 10.0$ & $80.4^{c} \pm 0.9$ & $128.5^{\mathrm{e}} \pm 2.1$ \\
\hline 1 week & $126.2^{b} \underset{(4)}{ \pm} 11.6$ & $\begin{array}{c}71.3^{c} \pm 0.9 \\
(8)\end{array}$ & $\begin{array}{c}156.1^{\mathrm{e}} \pm 6.0 \\
(12)\end{array}$ \\
\hline 3 weeks & $\begin{array}{c}171.1^{\mathrm{a}, \mathrm{b}} \pm \mathbf{( 1 0 )} \\
(10.6\end{array}$ & $\begin{array}{c}51.5^{d} \pm 0.7 \\
(5)\end{array}$ & $\begin{array}{c}139.7 f \pm \\
(6)\end{array}$ \\
\hline 5 weeks & $150.1 \underset{(6)}{ \pm}$ & $\begin{array}{c}51.5^{d} \pm 0.7 \\
(8)\end{array}$ & $145.8 \underset{(4)}{ \pm} 15.1$ \\
\hline 8 weeks & $161.0 \underset{(5)}{ \pm} 9.5$ & $64.1^{c} \pm 1.1$ & $\underset{(9)}{138.1 f} \pm 8.1$ \\
\hline
\end{tabular}

The values are in per cent of body weight \pm s.e.m. In brackets the number of pigs.

a The values are significantly different $(P<0.05)$.

b The values are significantly different $(P<0.05)$.

c The value is significantly different $(P<0.05)$ from all other age groups.

d The values are equal but significantly different $(P<0.05)$ from all other age groups.

e The values are significantly different $(P<0.05)$.

f The values are significantly different $(P<0.05)$ from the 1 week old group.

\section{Sulphadimidine}

The elimination of sulphadimidine also follows first-order kinetics throughout the entire period being studied.

From Table 1 it can be seen that the plasma half-life tends to increase from birth until 3 weeks of age and then to decrease to values below that of newborn. Only in the 8 weeks old pigs the half-life is significantly $(\mathrm{P}<0.05)$ lower than half-lives in the other groups of age.

The apparent specific volume of distribution (Table 2) is high in the newborn and decreases fast during the first 3 weeks of life. Then it increases from 5 to 8 weeks of age. All these differences are statistically significant $(P<0.05)$. 
T a b l e 3. Effect of age on the duration of hexobarbital sleeping time and plasma concentration of hexobarbital at the time of recovery.

\begin{tabular}{lcc}
\hline $\begin{array}{l}\text { Age of } \\
\text { pigs }\end{array}$ & $\begin{array}{c}\text { Hexobarbital } \\
\text { sleeping time }\end{array}$ & $\begin{array}{c}\text { Plasma concentration of } \\
\text { hexobarbital at recovery }\end{array}$ \\
\hline newborn & $219^{\mathrm{a}} \pm 4$ & $16.5 \pm 0.9$ \\
& $(4)$ & $(4)$ \\
1 week & $56^{\mathrm{a}} \pm 8$ & $18.4 \pm 1.6$ \\
$(8)$ & $(4)$ \\
3 weeks & $36 \pm 6$ & $15.2 \pm 1.0$ \\
5 weeks & $(11)$ & $(6)$ \\
8 weeks & $31 \pm 4$ & $17.8 \pm 1.3$ \\
& $30 \pm 1$ & $(6)$ \\
& $(5)$ & $15.8 \pm 0.8$ \\
\end{tabular}

* The values are in minutes \pm s.e.m.

* The values are in $\mu \mathrm{g}$ per $\mathrm{ml} \pm$ s.e.m.

In brackets the number of pigs.

a The value is significantly different $(P<0.05)$ from all other age groups.

Table 4 shows the calculated percentage of $\mathrm{N}^{4}$-acetylated sulphadimidine in plasma at 200 min. after the injection, and it can be seen that the values vary from 13.5 to 19.6 .

\section{Chloramphenicol}

The elimination of chloramphenicol follows first-order kinetics during the observation period. Plasma disappearance of injected chloramphenicol is slowest in the newborns and increases fast until 8 weeks of life (Table 1 ).

The apparent specific volume of distribution (Table 2) is high and it is increasing during the first week of life and then decreasing until 3 weeks of age. From this time the volume is unchanged with age and similar to that of newborns.

Table 4 shows the calculated percentage of chloramphenicol metabolites in plasma at $100 \mathrm{~min}$. after the injection, and it is seen that the values are increasing very fast during the whole observation period, particularly during the first week of life and from third to fifth week of age. 
T a b l e 4. Effect of age on the concentration in plasma of $\mathbf{N}^{4}$-acetylated sulphadimidine at 200 and chloramphenicol metabolites at 100 min. after the injection.

\begin{tabular}{|c|c|c|}
\hline $\begin{array}{l}\text { Age of } \\
\text { pigs }\end{array}$ & $\begin{array}{l}\mathrm{N}^{4} \text {-acetylated } \\
\text { sulphadimidine }\end{array}$ & $\begin{array}{l}\text { Chloramphenicol } \\
\text { metabolites }\end{array}$ \\
\hline newborn & $13.5 \underset{(5)}{ \pm} 1.3$ & $17.9^{\mathrm{c}} \pm 3.7$ \\
\hline 1 week & $19.6^{a} \pm 1.3$ & $\begin{array}{c}43.5^{d} \pm 3.4 \\
(12)\end{array}$ \\
\hline 3 weeks & $17.8^{\mathrm{a}} \pm 0.6$ & $49.9 \mathrm{~d} \pm 5.4$ \\
\hline 5 weeks & $\begin{array}{c}15.1 b \pm 0.6 \\
(8)\end{array}$ & $70.6^{\mathrm{e}} \pm 5.6$ \\
\hline 8 weeks & $\begin{array}{c}14.8^{b} \pm 1.2 \\
(8)\end{array}$ & $\begin{array}{c}78.2^{e} \pm 1.6 \\
(9)\end{array}$ \\
\hline
\end{tabular}

The values are concentration of metabolites in per cent of total drug \pm s.e.m. In brackets the number of pigs.

a The value is significantly different $(P<0.05)$ from the newborn group.

b The value is significantly different $(P<0.05)$ from the 1 week old group.

c The value is significantly different $(P<0.05)$ from all other age groups.

d The values are equal but significantly different $(P<0.05)$ from all other age groups.

e The values are equal but significantly different $(P<0.05)$ from all other age groups.

\section{DISCUSSION}

Half-life of hexobarbital and chloramphenicol is decreasing during the first 8 weeks of life. Decrease in half-life similar to that found in this study has been reported for several drugs both in animals and humans. e.g. tetracycline derivatives (Sereni et al. 1965), sulfisoxazol, sulfamoxole, sulfamethoxine and sulfamethoxypyrazine (Gladtke \& Rind 1965, Krauer et al. 1968, Sereni et al. 1968), chloramphenicol (Nishimura 1967), penicillins (Ingall \& Klein 1967, Simon et al. 1972), trimethoprim (Schulz 1972, Rasmussen 1973), and salicylate (Davis et al. 1973).

The decrease in half-life during the neonatal period can mainly be explained by increase in hepatic drug metabolism 
(Fouts 1968, 1973, Rane et al. 1973) and renal excretion Barnett \& Vesterdal 1953, Horster \& Lewy 1970).

In contrast to the renal excretory capability the hepatic drug metabolism has been studied in neonatal and young pigs by Short (1969), Short \& Davis (1970) and Short \& Stith (1973) and according to their findings the development of hepatic microsomal drug metabolizing enzyme activity reached maximum level at the age of 3 to 6 weeks.

Pharmacokinetic parameters of drugs are influenced by plasma protein binding capacity and volumes of body fluid compartments. Plasma protein binding capacity has been reported to be low in neonatal humans (Ganshorn \& Kurz 1968, Chignell et al. 1971, Ehrnebo et al. 1971, Pruitt \& Dayton 1971) and in newborn pigs (Svendsen et al. 1972, Short \& Tumbleson 1973). Thus the amount of unbound freely diffusable chloramphenicol in plasma of newborn infants is 1.4 to 2.0 times higher than the values in adult humans (Ganshorn \& Kurz). Both the total body water and extracellular fluid compartments have been shown to decrease with age in the beagle dog (Sheng \& Huggins 1972).

The decrease in hexobarbital sleeping time followed the decrease in hexobarbital half-life, and the concentration of hexobarbital in plasma at recovery was unchanged with age. These findings support that the age related decrease in half-life and sleeping time is influenced by increase in hexobarbital metabolism.

Hexobarbital is concentrated in the fat of the body, and the establishment of diffusion equilibrium with the fat depots takes several hours. According to Manners \& McCrea (1963) and Brooks \& Davis (1969) the percentage of fat in the body of newborn pigs is $1.2 \%$ and in 4 weeks old pigs $17.8 \%$. This age related difference in fat content easily explains the observed increase in the apparent specific volume of distribution of hexobarbital. The age related decrease in hexobarbital half-life and hexobarbital sleeping time of this study might therefore also reflect the increased fat content to the body.

The finding in this study that hexobarbital sleeping time is decreasing fast during the first 3 weeks of age is in agreement with Donald \& Raventós (1939) using pigs and Catz \& Yaffe (1967) using mice. Catz \& Yaffe also demonstrated constant plasma concentration of hexobarbital at the time of awakening in mice of different ages. 
The half-life of sulphadimidine tends to increase from birth until 3 weeks of age and is then decreasing significantly and so is the level of sulphadimidine in plasma at zero time. The longer half-life of sulphadimidine in 3 weeks old pigs compared to newborn pigs can not be explained as an effect of decreasing metabolic activity because the amount of $\mathrm{N}^{4}$-acetylated sulphadimidine is a little higher in 3 weeks old pigs than in newborn pigs.

Chloramphenicol is primarily inactivated by glucuronic acid conjugation and in less amount by hydrolysis, dehalogenation and formation of aryl amines (Glazko 1967). All these metabolic products are highly water soluble, particularly the glucuronidation products and this should be kept in mind when evaluating the very high percentage of chloramphenicol metabolites in plasma 100 min. after the injection in 5 and 8 weeks old pigs.

In rats and dogs nearly 80 and $50 \%$ of a dose of chloramphenicol is recovered as metabolites in the bile (Glazko et al. 1949, 1952). In newborn rats the biliary excretion capacity is low (Klaassen 1972) as is the renal excretory capacity. This suggests that the relatively high percentage of chloramphenicol metabolites in plasma of the newborn pigs at $100 \mathrm{~min}$. after the injection is reflecting more than the metabolic activity compared to the 8 weeks old pigs.

The plasma level of chloramphenicol in newborn infants is found to be higher than the level in children (Glazko) which is corresponding with the findings of this study.

The half-life of total chloramphenicol is found to be $1.3 \mathrm{hrs}$. in adult pigs (Davis et al. 1972). This is a little higher than the half-life of active chloramphenicol in the 8 weeks old pigs of this study.

From the present study it has been demonstrated that pharmacokinetic investigations are easily performed in neonatal and young pigs and that neonatal pigs pharmacokinetically are showing age-related changes similar to those of neonatal humans and neonatal animal species. In conclusion it must therefore be stressed that the neonatal pig is a convenient model for pharmacokinetic testing of drugs used as pharmacotherapeutics in neonatal life.

\section{ACKNOWLEDGEMENTS}

The author wishes to thank mrs. Lis Bærendsen and mr. Ernst Eriksen for skilful technical assistance during the work. 


\section{REFERENCES}

Barnett, H. L. \& J. Vesterdal: The physiologic and clinical significance of immaturity of kidney function in young infants. J. Pediat. $1953,42,99-119$.

Basu, T. K., J. W. T. Dickerson \& D. V. W. Parke: Effect of development on the activity of microsomal drug-metabolizing enzymes in rat liver. Biochem. J. 1971, 124, 19-24.

Bessman, S. P. \& S. Stevens: A colorimetric method for the determination of chloromycetin in serum and plasma. J. Lab. clin. Med. 1950, 35, $129-134$.

Bratton, A. C. \& E. K. Marshall: A new coupling component for sulfonamide determination. J. biol. Chem. 1939, 128, 537-550.

Brooks, C. C. \& J. W. Davis: Changes in the perinatal pig. J. Animal Sci. 1969, 99, 325-329.

Butler, T. C.: The distribution of drugs. In Fundamentals of Drug Metabolism and Drug Disposition. ed. B. N. LaDu, H. G. Mandel \& E. L. Way. The Williams \& Wilkins Company, Baltimore 1971, pp. $44-62$.

Catz, C. \& S. J. Yaffe: Strain and age variations in hexobarbital response. J. Pharmacol. exp. Ther. 1967, 155, $152-156$.

Chignell, G. F., E. S. Vesell, D. K. Starkweather \& C. M. Berlin: The binding of sulfaphenazole to fetal, neonatal, and adult human plasma albumin. Clin. Pharmacol. Ther. 1971, 12, 897-901.

Cooper, J. R. \& B. B. Brodie: The enzymatic metabolism of hexobarbital (evipan). J. Pharmacol. exp. Ther. 1955, 114, 409-417.

Davis, L. E., C. A. Neff \& J. D. Baggot: Comparative pharmacokinetics in domesticated animals. Nat. Conf. Res., Animals in Med., Washington, D.C., Jan. 1972.

Davis, L. E., B. A. Westfall \& C. R. Short: Biotransformation and pharmacokinetics of salicylate in newborn animals. Amer. J. vet. Res. $1973,34,1105-1108$.

Donald, H. P. \& J. Raventós: Influence of age and weight of pigs on response to sodium evipan. J. Pharmacol. exp. Ther. 1939, 65, $383-388$.

Done, A. K.: Perinatal pharmacology. Ann. Rev. Pharmacol. 1966, 6, 189-208.

Ehrnebo, M., S. Agurell, B. Jalling \& L. O. Boréus: Age differences in drug binding by plasma proteins: Studies on human foetuses, neonates and adults. Europ. J. clin. Pharmacol. 1971, 3, 189193.

Fichter, E. G. \& J. A. Curtis: Sulfonamide administration in newborn and premature infants. Pediatrics 1956, 18, 50-59.

Fouts, J. R.: Hepatic microsomal drug metabolism in the perinatal period. In Diagnosis and Treatment of Fetal Disorders. ed. K. Adamson. Springer Verlag, N.Y. 1968, pp. 291-304.

Fouts, J. R.: Microsomal mixed-function oxidases in the fetal and newborn rabbit. In Fetal Pharmacology. ed. L. Boréus. Raven Press, New York 1973, pp. 305-320. 
Fouts, J. R. \& R. H. Adamson: Drug metabolism in the newborn rabbit. Science 1959, 129, 897-898.

Ganshorn, A. \& H. Kurz: Unterschiede zwischen der Proteinbindung Neugeborener und Erwachsener und ihre Bedeutung für die pharmakologische Wirkung. (Differences between protein binding in newborns and adults and influence on pharmacologic action). Naunyn-Schmiedeberg's Arch. Pharmacol. 1968, 260, $117-118$.

Gladtke, E. \& H. Rind: Sulfonamide bei unreifen und reifen Trimenonkindern. 3rd Int. Congr. Chemotherapy, Stuttgart 1965, pp. $656-659$.

Glazko, A. J.: Identification of chloramphenicol metabolites and some factors affecting metabolic disposition. In Antimicrobial Agents and Chemotherapy. ed. G. L. Hobby, American Society for Microbiology 1967.

Glazko, A. J., L. M. Wolf, W. A. Dill \& A. C. Bratton: Biochemical studies on chloramphenicol (Chloromycetin). II. Tissue distribution and excretion studies. J. Pharmacol. exp. Ther. 1949, 96, $445-459$.

Glazko, A. J., W. A. Dill \& L. M. Wolf: Observation on the metabolic disposition of chloramphenicol (Chloromycetin) in the rat. J. Pharmacol. exp. Ther. 1952, 104, 452-458.

Henderson, P. T.: Metabolism of drugs in rat liver during the perinatal period. Biochem. Pharmacol. 1971, 20, 1225-1232.

Horster, M. \& J. E. Lewy: Filtration fraction and extraction of PAH during neonatal period in the rat. Amer. J. Physiol. 1970, 219, 1061-.1065.

Hughes, D. W. O. \& L. K. Diamond: Chloramphenicol in blood: Simple chemical estimations in patients receiving multiple antibiotics. Science 1964, 144, 296-297.

Ingall, D. \& J. O. Klein: Levels of penicillins in serum of newborn infants. 5th Int. Congr. Chemotherapy 1967, 1, 407-410.

Jondorf, W. R., R. T. Maickel \& B. B. Brodie: Inability of newborn mice and guinea pigs to metabolize drugs. Biochem. Pharmacol. $1958,1,352-354$.

Kakemi, K., T. Arita \& S. Ohashi: Absorption and excretion of drugs. IV. Determination of chloramphenicol in blood. Yakugaku Zasshi. (J. Pharm. Soc. Jap.) 1962, 82, 342-345.

Kemp, T.: Statistik for medicinere. (Statistics for physicians). Munksgaard, Copenhagen 1955.

Klaassen, C. D.: Immaturity of the newborn rat's hepatic excretory function for ouabain. J. Pharmacol. exp. Ther. 1972, 183, 520526.

Krauer, B., P. Spring \& L. Dettli: Zur Pharmakokinetik der Sulfonamide im ersten Lebensjahr. (Pharmacokinetics of sulphonamides in the first year of life). Pharmacol. Clin. 1968, 1, 47-53.

Manners, M. J.\& M. R. McCrea: Changes in the chemical composition of sow-reared piglets during the 1st month of life. Brit. J. Nutr. $1963,17,495-513$. 
Mirkin, B. L.: Developmental pharmacology. Ann. Rev. Pharmacol. $1970,10,255-271$.

Nishimura, T.: Chloramphenicol in the newborn and premature infants - Absorption and excretion of chloramphenicol. 5th Int. Congr. Chemotherapy 1967, 1, 401-405.

Nyhan, W. L.: Toxicity of drugs in the neonatal period. J. Pediat. $1961,59,1-20$.

Pruitt, A. W. \& P. G. Dayton: A comparison of the binding of drugs to adult and cord plasma. Europ. J. clin. Pharmacol. 1971, 4, $59-62$.

Rane, A., M. Berggren, S. Yaffe \& J. L. E. Ericsson: Oxidative drug metabolism in the perinatal rabbit liver and placenta. A biochemical and morphologic study. Xenobiotica 1973, 3, 37-48.

Rasmussen, Folke: Personal communication, 1973.

Schulz, R.: Distribution and elimination of trimethoprim in pregnant and newborn rats. Naunyn-Schmiedeberg's Arch. Pharmacol. $1972,272,369-377$.

Sereni, F., L. Perletti, N. Manfredi \& A. Marini: Tissue distribution and urinary excretion of a tetracycline derivative in newborn and old infants. J. Pediat. 1965, 67, 299-305.

Sereni, F., L. Perletti, E. Marubini \& G. Mars: Pharmacokinetic studies with a long-acting sulfonamide in subjects of different ages. Pediat. Res. 1968, 2, 29-37.

Sheng, H. \& R. A. Huggins: Growth of the beagle: Changes in the body fluid compartment. Proc. Soc. exp. Biol. (N. Y.) 1972, 139, $330-335$.

Short, C. R.: Drug metabolism in newborn swine. Diss. Abstr. Int. $1969,30 \mathrm{~B}, 1826$.

Short, C. R. \& L. E. Davis: Perinatal development of drug-metabolizing enzyme activity in swine. J. Pharmacol. exp. Ther. 1970, 174, $185-196$.

Short, C. R. \& R. D. Stith: Perinatal development of hepatic microsomal mixed function oxidase activity in swine. Biochem. Pharmacol. 1973, 22, 1309-1319.

Short, C. R. \& M. E. Tumbleson: Binding of drugs to plasma proteins of swine during the perinatal period. Toxicol. appl. Pharmacol. 1973, 24, 612-624.

Simon, C., M. Bekesch \& V. Malerczyk: Zur Pharmakokinetik von Penicillin V im Kindersalter (insbesondere bei Neugeborenen). (Pharmacokinetics of penicillin $\mathrm{V}$ in childhood (especially in newborns)). Med. Welt (Stuttg.) 1972, 23, 1717-1721.

Svendsen, J., M. R. Wilson \& E. Ewert: Serum protein levels in pigs from birth to maturity and in young pigs with and without enteric colibacillosis. Acta vet. scand. 1972, 13, 528-538.

Yaffe, S. J.: Some aspects of perinatal pharmacology. Ann. Rev. Med. $1966,17,213-234$. 


\section{SAMMENDRAG}

Farmakokinetik af enhexymal, sulfadimidin og chloramphenicol hos neonatale og unge grise.

Halveringstiden og fordelingsvolumenet af enhexymal, sulfadimidin og chloramphenicol er unders $\varnothing$ gt hos nyf $\varnothing$ dte, $1,3,5$ og 8 uger gamle grise. Enhexymal-sovetiden er målt og koncentrationen af enhexymal i plasma ved sovetidens oph $\phi \mathbf{r}$ er beregnet hos de samme aldersgrupper.

Halveringstiden af enhexymal og chloramphenicol er meget lang hos nyf $\varnothing$ dte grise, men den afkortes hurtigt efter fødselen, specielt i l løbet af den første leveuge. Halveringstiden af sulfadimidin forlænges i løbet af de første 3 leveuger. To hundrede min. efter injektionen er mængden af $\mathrm{N}^{4}$-acetyleret sulfadimidin i plasma højere hos 1 og 3 uger gamle grise end hos nyfødte grise.

Fordelingsvolumenet af enhexymal, sulfadimidin og chloramphenicol ændres på forskellig måde i løbet af de første 8 leveuger. Enhexymal-sovetiden er meget lang hos nyf $\varnothing$ dte grise og falder indtil 3 uger efter fødselen. Koncentrationen af enhexymal i plasma ved sovetidens oph $\phi r$ er uforandret fra f $\varnothing$ dsel til 8 uger efter f $\varnothing$ dselen.

Koncentrationen af chloramphenicolmetabolitter i plasma 100 min. efter injektionen stiger stærkt fra f $\varnothing$ dsel til 8 uger efter f $\varnothing$ dselen. Koncentrationen af $\mathrm{N}^{4}$-acetyleret sulfadimidin i plasma $200 \mathrm{~min}$. efter injektionen stiger fra f $\phi$ dsel til f $\varnothing$ rste leveuge og falder derefter.

På grundlag af unders $\varnothing$ gelsens resultater konkluderes det, at neonatale grise er en anvendelig dyremodel til farmakokinetiske undersøgelser af lægemidler, som anvendes $\mathrm{i}$ den neonatale farmakoterapi.

(Received January 6, 1975).

Reprints may be requested from: Ove Svendsen, Department of Pharmacology and Toxicology, H. Lundbeck \& Co. A/S, Ottiliavej 7-9, DK-25010 Copenhagen-Valby, Denmark. 